\title{
KEMAMPUAN PERAWAT DALAM MEMBERIKAN DIAGNOSA KEPERAWATAN TERHADAP PASIEN ANEMIA
}

\author{
Ade Sulistya Lubis/181101121 \\ adesulistyalubis@gmail.com
}

\begin{abstract}
Abstrak
Latar belakang: Diagnosa keperawatan adalah langkah kedua dari proses keperawatan yang menggambarkan penilaian klinis tentang respon individu, keluarga, kelompok maupun masyarakat terhadap permasalahan kesehatan baik aktual maupun potensial. Tujuan: Tujuan pembandigan dari beberapa jurnal dan sumber lainnya agar dapat mengetahui bagagaimana kemampuan perawat dalam memberikan diagnosis keperawatan terhadap pasien Anemia. Metode: Jurnal ini menggunakan metode tersearch dan analisis dari berbagai sumber seperti buku teks, buku referensi jurnal, e-book, dan juga membandingkan beberapa jurnal yang berhubungan dengan kemampuan perawat dalam memberikan diagnosis keperawatan terhadap pasien Anemia. Hasil: Pemberian diagnose keperawatan terhadap pasien yang terkena anemia harus mengetahui dan dapat berfikir secara kritis agar dapat memberikan diagnose yang tepat.

Kesimpulan: Dari beberapa pembandingan jurnal dapat diketahui bahwa kemampuan perawat dalam memberikan diagnose keperawatan pada pasien anemia sangat diperlukan untuk tercapainya pelayanan kesehatan yang optimal dengan asuhan keperawatan yang bermutu.
\end{abstract}

Kata Kunci: Perawat, Diagnosa Keperawatan, Anemia

Background: Nursing diagnosis is the second step of the nursing process that describes the clinical assessment of individual, family, group and community responses to health problems both actual and potential. Objective: The purpose of comparison of several journals and other sources in order to find out how the nurse's ability to provide nursing diagnoses to Anemia patients. Methods: This journal uses the search method and analysis from various sources such as textbooks, journal reference books, e-books, and also compares journals related to nurses' ability to provide nursing diagnoses to Anemia patients. Results: Giving a nursing diagnosis to patients affected by anemia must know and be able to think critically in order to provide a proper diagnosis.

Conclusion: From several journal comparisons it can be seen that the ability of nurses in providing nursing diagnoses in anemic patients is very necessary for the achievement of optimal health services with quality nursing care.

Keywords: Nurse, Nursing Diagnosis, Anemia 


\section{PENDAHULUAN}

\section{LATAR BELAKANG}

Diagnosa keperawatan adalah suatu kesimpulan yang dihasilkan dari analisa data (Carpenito, 2009). Diagnosa keperawatan adalah penilaian klinik tentang respon individu keluarga, atau komunitas terhadap masalah kesehatan atau proses kehidupan yang aktual atau potensia. Diagnosa keperawatan memberikan dasar untuk pemilihan intervensi keperawatan untuk mencapai hasil yang merupakan tanggung jawab perawat menurut North American Nursing Diagnosis Association (NANDA) (1990, dalam Allen, 1998).

Perawat sebagai pemberi asuhan keperawatan diharapkan mampu memberikan pelayanan keperawatan profesional kepada individu, keluarga, dan masyarakat secara mandiri dan kolaborasi dengan tim kesehatan lain. (Kozier, 2005).

Anemia adalah istilah yang menunjukan rendahnya hitungan sel darah merah dan kadar hemoglobin dan hematokrit di bawah normal(Smeltzer,2002:935).

Anemia adalah berkurangnya hingga di bawah nilai normal sel darah merah, kualitas hemoglobin dan volume packed red bloods cells (hematokrit) per $100 \mathrm{ml}$ darah (Price, 2006 : 256). Dengan demikian anemia bukan merupakan suatu diagnosis atau penyakit, melainkan merupakan pencerminan keadaan suatu penyakit atau gangguan fungsi tubuh dan perubahan patotisiologis yang mendasar yang diuraikan melalui anemnesis yang seksama, pemeriksaan fisik dan informasi laboratorium.

\section{TUJUAN}

Tujuan pembandigan dari beberapa jurnal dan sumber lainnya agar dapat mengetahui bagaimana kemampuan perawat dalam memberikan diagnosis keperawatan terhadap pasien Anemia.

\section{METODE}

Jurnal ini menggunakan metode tersearch dan analisis dari berbagai sumber seperti buku teks, buku referensi jurnal, e-book, dan juga membandingkan beberapa jurnal yang berhubungan dengan kemampuan 
perawat dalam memberikan diagnosis keperawatan terhadap pasien Anemia. Dari analisi berbagai sumber digunakan Untuk mengetahui kemampuan perawat dalam memberikan diagnose keperawatan terhadap pasien Anemia. Penulisan jurnal ini dimulai pada tanggal 12 oktober 2019. Pengolahan jurnal dilakukan dengan metode membandingkan beberapa jurnal yang berhubungan dengan kemampuan perawat dalam memberikan diagnose keperawatan terhadap pasien Anemia.

\section{HASIL}

\section{Dari hasil pembandingan Jurnal} pertama (Roymond H. Simamora, dkk(2017). Penguatan Kinerja Perawat Dalam Pemberian Asuhan Keperawatan Melalui Pelatihan Ronde Keperawatan Di Rumah Sakit Royal Prima Medan: Volume 23 No. 2, ISSN: 0852-2715 |eISSN: 2502-7220) Perawat sebagai salah satu faktor yang mempengaruhi kualitas asuhan keperawatan dan merupakan faktor yang paling menentukan untuk tercapainya pelayanan kesehatan yang optimal dengan asuhan keperawatan yang bermutu. Untuk dapat melaksanakan asuhan keperawatan dengan baik seorang perawat perlu memiliki kemampuan berhubungan dengan klien dan keluarga, serta berkomunikasi dengan anggota tim kesehatan lain, mengkaji kondisi kesehatan klien baik melalui wawancara, pemeriksaan fisik maupun menginterprestasikan hasil pemeriksaan penunjang, menetapkan diagnosis keperawatan dan memberikan tindakan yang dibutuhkan klien, mengevaluasi tindakan keperawatan yang telah diberikan serta menyesuaikan kembali perencanaan yang telah dibuat dan sebagainya (Gibson et al.,1997).

Dari hasil junal kedua (Josua Edison, Mangole Sefty Rompas, A. Yudi Ismanto (2015). Hubungan Perilaku Perawat Dengan Pendokumentasian Asuhan Keperawatan Di Cardiovaskular And Brain Center Rsup Prof. Dr. R. D. Kandou Manado: E-journal Keperawatan (e-Kp) Volume 3 Nomor 2). Menurut Potter \& Perry (2005), sebagai anggota dari tim perawatan kesehatan, perawat harus mengkomunikasikan informasi tentang klien secara akurat. Kualitas perawatan klien bergantung pada kemampuan pemberi perawatan untuk berkomunikasi satu sama lain. 
Diagnosa keperawatan adalah suatu penyatuan dari masalah pasien yang nyata maupun potensial berdasarkan data yang telah dikumpulkan (Boedihartono, 1994).

Diagnosa keperawatan yang muncul pada pasien dengan anemia (Doenges, 1999) meliputi:

1. Risiko tinggi terhadap infeksi berhubungan dengan tidak adekuatnya pertahanan sekunder (penurunan hemoglobin leucopenia, atau penurunan granulosit (respons inflamasi tertekan)).

2. Perubahan nutrisi kurang dari kebutuhan tubuh berhubungan dengan kegagalan untuk mencerna atau ketidak mampuan mencerna makanan /absorpsi nutrient yang diperlukan untuk pembentukan sel darah merah.

3. Intoleransi aktivitas berhubungan dengan ketidakseimbangan antara suplai oksigen (pengiriman) dan kebutuhan.

4. Perubahan perfusi jaringan berhubungan dengan penurunan komponen seluler yang diperlukan untuk pengiriman oksigen/nutrient ke sel.

5. Risiko tinggi terhadap kerusakan integritas kulit berhubungan dengan perubahan sirkulasi dan neurologist.

6. Konstipasi atau Diare berhubungan dengan penurunan masukan diet; perubahan proses pencernaan; efek samping terapi obat.

7. Kurang pengetahuan sehubungan dengan kurang terpajan/mengingat ; salah interpretasi informasi ; tidak mengenal sumber informasi.

\section{PEMBAHASAN}

Diagnosa keperawatan adalah langkah kedua dari proses keperawatan yang menggambarkan penilaian klinis tentang respon individu, keluarga, kelompok maupun masyarakat terhadap permasalahan kesehatan baik aktual maupun potensial. Dimana perawat mempunyai lisensi dan kompetensi untuk mengtasinya ( Sumijatun, 2010 ).

Diagnosa keperawatan adalah pernyataan yang jelas, singkat dan pasti tentang masalah pasien yang nyata serta 
penyebabnya dapat dipecahkan atau diubah melalui tindakan keperawatan menurut Gordon (1982, dalam Dermawan, 2012).

Kemampuan perawat dalam memberikan diagnose keperawatan terhadap pasien anemia harus mengetahui apa yang dimaksud dengan anemia. Pemberian diagnose keperawatan terhadap pasien yang terkena anemia juga harus dapat berfikir secara kritis agar dapat memberikan diagnose yang tepat.

Anemia adalah gejala dari kondisi yang mendasari, seperti kehilangan komponen darah, elemen tak adekuat atau kurangnya nutrisi yang dibutuhkan untuk pembentukan sel darah merah, yang mengakibatkan penurunan kapasitas pengangkut oksigen darah (Doenges, 1999).

Timbulnya anemia mencerminkan adanya kegagalan sumsum tulang atau kehilangan sel darah merah berlebihan atau keduanya. Kegagalan sum-sum tulang dapt terjadi akibat kekurangan nutrisi, pajanan toksik, inuasi tumor, atau kebanyakan akibat penyebab yang tidak diketahui. Sel darah merah dapat hilang melalui perdarahan atau hemolisis (destruksi) pada kasus yang disebut terakhir, masalah dapat akibat efek sel darah merah yang tidak sesuai dengan ketahanan sel darah merah normal atau akibat beberapa factor diluar sel darah merah yang menyebabkan destruksi sel darah merah.

$$
\text { Lisis sel darah merah (disolusi) }
$$
terjadi terutama dalam system fagositik atau dalam system retikuloendotelial terutama dalam hati dan limpa. Sebagai hasil samping proses ini bilirubin yang sedang terbentuk dalam fagosit akan masuk dalam aliran darah. Setiap kenaikan destruksi sel darah merah (hemolisis) segera direpleksikan dengan meningkatkan bilirubin plasma (konsentrasi normalnya $1 \mathrm{mg} / \mathrm{dl}$ atau kurang ; kadar 1,5 mg/dl mengakibatkan ikterik pada sclera.

Anemia merupakan penyakit kurang darah yang ditandai rendahnya kadar hemoglobin $(\mathrm{Hb})$ dan sel darah merah (eritrosit). Fungsi darah adalah membawa makanan dan oksigen ke seluruh organ tubuh. Jika suplai ini kurang, maka asupan oksigen pun akan kurang. Akibatnya dapat menghambat kerja organ-organ penting, Salah satunya otak. Otak terdiri dari 2,5 miliar sel bioneuron. Jika kapasitasnya kurang, 
maka otak akan seperti komputer yang memorinya lemah, Lambat menangkap. Dan kalau sudah rusak, tidak bisa diperbaiki (Sjaifoellah, 1998).

\section{PENUTUP}

\section{KESIMPULAN}

Perawat sebagai salah satu faktor yang mempengaruhi kualitas asuhan keperawatan dan merupakan faktor yang paling menentukan untuk tercapainya pelayanan kesehatan yang optimal dengan asuhan keperawatan yang bermutu. Untuk dapat melaksanakan asuhan keperawatan dengan baik seorang perawat perlu memiliki kemampuan berhubungan dengan klien dan keluarga,

\section{SARAN}

Perawat sebagai pemberi asuhan keperawatan diharapkan mampu memberikan pelayanan keperawatan profesional kepada individu, keluarga, dan masyarakat secara mandiri dan kolaborasi dengan tim kesehatan lain.

\section{REFERENSI}

Barker, Linsey, M., Nussbaum, Maury, A. (2011). Fatique, performance and the work environment ; a survey of registered nurses. Journal of Advanced Nursing $\mathbf{J}$ ADV NURS, 67(6), 1370-82

Boedihartono. 1994. Proses Keperawatan di Rumah Sakit. Jakarta.

Burton, J.L. 1990. Segi Praktis Ilmu Penyakit Dalam. Binarupa Aksara : Jakarta

Carpenito, Lynda Juall. (2000). Buku Saku Diagnosa Keperawatan. Edisi 8. Jakarta : EGC

Carpenito, L. J. 1999. Rencana Asuhan keperawatan dan dokumentasi keperawatan, Diagnosis Keperawatan dan Masalah Kolaboratif, ed. 2. EGC : Jakarta Doenges, Marilynn E. 1999. Rencana Asuhan Keperawatan pedoman untuk 2015 perencanaan dan pendokumentasian pasien. ed.3. EGC : Jakarta

Departemen Kesehatan RI.(2010). Standar Asuhan Keperawatan: Jakarta.

Josua Edison, Mangole Sefty Rompas, A. Yudi Ismanto (2015). Hubungan Perilaku Perawat Dengan Pendokumentasian Asuhan Keperawatan Di Cardiovaskular 
And Brain Center Rsup Prof. Dr.

R. D. Kandou Manado: Ejournal Keperawatan (e-Kp)

Volume 3 Nomor 2.

Simamora, Roymond H. dkk (2017). Penguatan Kinerja Perawat Dalam Pemberian Asuhan Keperawatan Melalui Pelatihan Ronde Keperawatan Di Rumah Sakit Royal Prima Medan: Volume 23 No. 2, ISSN: 08522715 | e-ISSN: 2502-7220

Simamora, R. H. (2019). Menjadi Perawat yang: CIHHUY. Surakarta: Kekata Publisher.

Simamora, R. H. (2019). Menjadi Perawat yang: CIH'HUY. Surakarta: Kekata Publisher.

Simamora, Roymond H. 2010. Komunikasi dalam Keperawatan, Ed 1 hal 210. Jember: Univesity Press.

Simamora, Roymond H. Dokumentasi Proses Keperawatan, 'Ed 1 hal 144. Jember: University Press.

Simamora, Roymond H. 2008. Peran Manajer dalam Pembinaan Etika
Perawat Pelakasanaan dalam Peningkatan Kualitas Pelayanan Asuhan Keperawatan: Jurnal IKESMA, Ed 4, 2.

Perry, A. G., \& Potter, P. A. (2009). Potter and perry's fundamentals of nursing Australian

Potter, P. A., \& Perry, A. G. (2005) Buku Ajar

Fundamental Keperawatan: Konsep, Proses dan Praktek (edisi 4). Jakarta : Penerbit Buku Kedokteran EGC.

Potter, P. A., \& Perry, A. G., (2010). Fundamental of nursing. Buku 1, edisi 7. Jakarta : Salemba Medika

Potter, P. A., \& Perry, A. G., (2013). Fundamentals of nursing. $\left(8^{\text {th }} \mathrm{ed}\right)$. Elsevier.

Supratti, Ashriady. Pendokumentasian Standar Asuhan Keperawatan di RSUD Mamuju, Indonesia. Vol 2. No 1, juli 2016: Jurnal Kesehatan MANARANG 